\title{
The Complexity of Heavy Work Investment (HWI): A Conceptual Integration and Review of Antecedents, Dimensions, and Outcomes
}

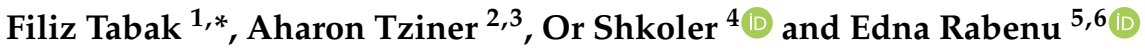 \\ 1 Department of Management, ST 116B, College of Business and Economics, 8000 York Rd., Towson University, \\ Towson, MD 21252, USA \\ 2 Department of Organizational Consulting \& Development, School of Business Administration, \\ Peres Academic Center, Shimon Peres St. 10, Rehovot 7610202, Israel; aetziner@pac.ac.il \\ 3 Schools of Law \& Business Administration, Netanya Academic College, University St. 1, \\ Netanya 4223587, Israel \\ 4 Department of Management, Business School, HEC Montréal, 3000 Chemin de la Côte-Sainte-Catherine, \\ Montréal, QC H3T 2A7, Canada; or.shkoler@gmail.com \\ 5 School of Organizational Behavior, Tel-Hai Academic College, Upper Galilee 1220800, Israel; \\ edna.rabenu@gmail.com \\ 6 School of Organizational Behavior, Netanya Academic College, University St. 1, Netanya 4223587, Israel \\ * Correspondence: tabak@towson.edu
}

Citation: Tabak, F.; Tziner, A.; Shkoler, O.; Rabenu, E. The Complexity of Heavy Work Investment (HWI): A Conceptual Integration and Review of Antecedents, Dimensions, and Outcomes. Sustainability 2021, 13, 7803. https://doi.org/10.3390/ su13147803

Academic Editors:

Horacio Molina-Sánchez,

Gabriele Giorgi, Dante

Castillo Guajardo and

Antonio Ariza-Montes

Received: 5 May 2021

Accepted: 2 July 2021

Published: 13 July 2021

Publisher's Note: MDPI stays neutral with regard to jurisdictional claims in published maps and institutional affiliations.

Copyright: (c) 2021 by the authors. Licensee MDPI, Basel, Switzerland. This article is an open access article distributed under the terms and conditions of the Creative Commons Attribution (CC BY) license (https:/ / creativecommons.org/licenses/by/ $4.0 /)$.
Abstract: The purpose of this paper is to bring conceptual clarity to the heavy work investment (HWI) construct while building a model based on a review of extant empirical and theoretical research and to encourage further discussion and investigations regarding the nature of HWI, specifically its individual level antecedents, dimensions, and outcomes for both the employee and the organization. The proposed theoretical framework builds upon the Job Demands-Resources model and conceptualizes HWI on a continuum of workaholism and work engagement. Specific propositions for the antecedents and outcomes of the HWI continuum are developed. The paper ends with a discussion of future research directions.

Keywords: heavy work investment; work engagement; workaholism

\section{Introduction}

Heavy employee investment of time and effort in work may have positive as well as negative outcomes for both the employee and the organization [1,2]. Examples of positive outcomes are higher job performance, job satisfaction, and lower turnover intentions, while negative outcomes can include burnout, stress, or work-life conflict [3-5]. Despite these significant likely outcomes, many questions are still unanswered in literature. What makes an employee invest heavily in work with both time and effort? Are there particular dispositional traits that affect this behavior? How do dispositional traits interact with situational factors to influence employee behavior? Which mechanisms are at play to determine whether there will be positive, negative, attitudinal, behavioral, affective, individual, or organizational outcomes of this behavior? This review paper aims to explore these questions and seeks to bring conceptual clarity to the construct of heavy work investment (HWI) while advancing theory.

HWI refers to the extra amount of time and energy an employee allocates to his or her work [6-8]. As an umbrella construct, HWI consists of two main dimensions: time commitment, as in working long hours, and work intensity, as in putting significant mental and physical effort into work [5]. HWI also encompasses two well-known sub-constructs, namely, workaholism and job engagement.

Workaholism has been conceptualized as an addiction to work involving behaviors such as compulsion and the drive to work due to internal pressures and working beyond a 
normally accepted set of expectations $[9,10]$. The definition of workaholism includes heavy time investment in work and yet does not necessarily take into account the intensity with which one performs during this time. However, the intensity of work is just as significant as the actual time invested in the work [5,11].

While workaholism carries negative implications of heavy work investment, work engagement pertains to positive involvement in work [12]. Work engagement is a " ... positive, fulfilling work-related state of mind, characterized by vigor, dedication, and absorption" [13] (p. 522). As such, work engagement dimensions include vigor referring to high effort and energy, dedication referring to commitment in one's work, and absorption referring to concentration and focus on work [14].

Recent investigations of workaholism and work engagement have shown that high combined levels are associated with a variety of negative and positive outcomes e.g., [15] Researchers have also started to investigate how workaholism and work engagement interact [16]. This paper develops an individual level conceptual model of HWI delineating workaholism and work engagement as two types of HWI and answering calls for more person-oriented research $[15,17]$. The purpose is to bring conceptual clarity to the HWI construct while building a model based on empirical and theoretical reviews of extant research and to encourage further discussion and investigations regarding the nature of HWI, specifically its individual level antecedents, dimensions, and outcomes for both the employee and the organization.

\section{Theoretical Framework}

The proposed framework of HWI uses the Job Demands-Resources (JD-R) model [18] and views the perceived organizational context and individual personality (dispositional) differences as either job resources or job demands that may impact individual behavior of heavy work investment. The JD-R model groups job characteristics into two categories: job demands and job resources. Job demands describe the job dimensions that carry significant personal costs with them that may lead to negative outcomes such as burnout and emotional exhaustion [19]. Job resources describe the job dimensions that may lead to work engagement, goal accomplishment, or personal and professional growth [20]. While job demands initiate a health impairment process due to prolonged experience of stress and emotional exhaustion, job resources create a motivational process where employees wish to be further engaged and stay engaged with their work [19]. The HWI framework developed here focuses on both the health impairment and the motivational processes described in the JD-R model and views HWI on a continuum. The proposed framework/model is depicted in Figure 1 composed of three major parts: antecedents, dimensions, and outcomes.

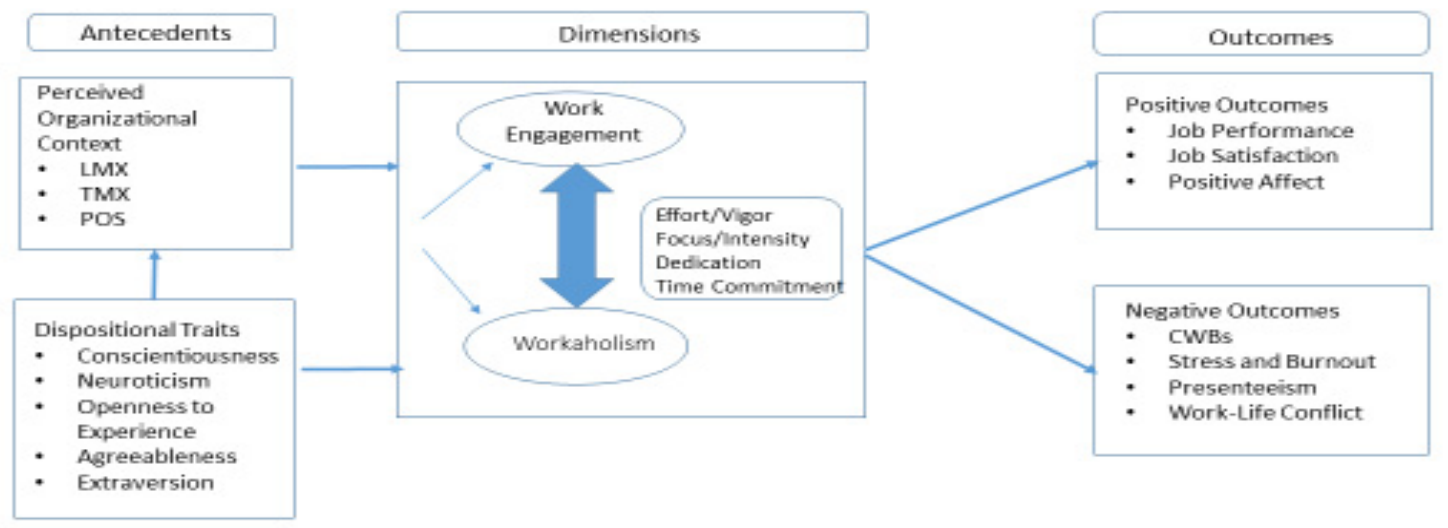

Figure 1. The Complexity of Heavy Work Investment (HWI): A Conceptual Integration of Antecedents, Dimensions, and Outcomes. 


\subsection{Multidimensionality of HWI}

HWI encompasses workaholism and work engagement as two distinct yet correlated sub-constructs [21]. While workaholism implies a dysfunctional form of HWI leading to mainly negative individual level outcomes, work engagement entails a functional form of HWI mostly resulting in positive individual level outcomes [22]. HWI has further been conceptualized as having two dimensions: the time invested in work and the intensity with which work is accomplished [5]; the time dimension is clearly part of the workaholism concept while intensity is subsumed under the work engagement concept. As each subconstruct seems to be associated with diverging functional and dysfunctional outcomes, an understanding of which variables precede each sub-construct is warranted so that organizations and individuals can strategize how to lower workaholism while at the same time augment work engagement.

The definition of workaholism has been originally forwarded as " ... the uncontrollable need to work incessantly" [23] (p. 11). More recently, a review of multiple definitions yielded the conclusion that workaholism is a type of addiction and can be identified with its three core dimensions as affect (such as joy while working but guilt when not working), cognition (such as obsession with working), and behavior (such as working excessive hours including while at home) [24]. Hence, workaholics typically enjoy themselves while working (affect), think a lot about work while not working (cognitive), and work for long hours (behavior). Workaholics seem to allocate little time to leisure activities or to family [25].

In an organizational context, as job demands exceed the job resources, employees are more likely to exhibit compulsive behavior, and hence we can expect more attitudes, cognitions, and behaviors typically associated with workaholism. As job resources exceed the job demands, employees are more likely to exhibit high levels of effort, focus, and dedication to their work and become more engaged, experiencing joy, happiness, and satisfaction and other behaviors and attitudes typically associated with work engagement. Where an abundance of job resources may motivate employees to become more engaged in their work, excessive job demands may lead to negative outcomes such as stress, burnout, or low job performance $[19,26,27]$. In situations where scarcity of resources is readily perceived along with a multitude of demands or challenges, the HWI continuum is likely to shift toward workaholism, and the opposite tendency is more likely when resources outweigh the job demands.

\subsection{Antecedents of HWI}

Over the last decade, researchers have explored a variety of antecedents of HWI, both empirically and conceptually $[6,8,9]$. Most work has discussed (a) individual predictors such as addiction to work, parenthood, education level, or passion for work and (b) situational predictors such as organizational culture or basic financial needs [5]. The framework presented here takes this line of thinking a step further and develops a completely personbased conceptual framework using the JD-R model [18]. Hence, the model asserts that the decision of whether to invest heavily in work or not depends on the individual's perception of the organizational context as well as the individual's personality.

While one contribution of this theoretical model is to investigate HWI from a completely individual level perceptual lens, a second contribution is to utilize the JD-R model to clarify how perceptual and personality-based antecedents associate with sub-constructs of workaholism and work engagement on a continuum of HWI. Job resources are job facets that facilitate employee work achievement [20]. A number of job resources such as rewards, recognition, job clarity, and supervisory and co-worker support have been identified in prior research as influencing work engagement [28]. Job demands, on the other hand, can be exhausting and can become antecedents to workaholism characterized by negative affect, negative cognition, or negative behaviors $[19,24]$. This model explores the impact of job resources and job demands on HWI from a dispositional and perceptual perspective, and proposes that when job resources exceed job demands, employees will tend to exhibit 
behaviors consistent with work engagement, and when job demands exceed job resources, employees will tend to act more in line with workaholism.

\subsubsection{Dispositional Traits}

Personality differences may create tendencies for individuals to prefer to invest heavily in work or not $[8,24]$. Both the individual dispositions and the socio-cultural experiences as well as behavioral reinforcements such as rewards may influence dimensions of workaholism [8]. Dispositional traits, such as personality, are associated with "motivational systems [that have an] affective core" [29] (p. 525). Often discussed in terms of behavior, cognition, and affect, traits influence an individual's perceptions and attitudes about work. For example, each of the Big Five traits may have different degrees of association with behavior, affective, and cognitive dispositions [30].

The Five Factor Model, also called the Big Five, describes personality across five dimensions: extraversion, agreeableness, conscientiousness, neuroticism, and openness to experience. An individual rated high in extraversion exhibits dominant, assertive, and persistence behavior [31]. They tend to want to be in charge and are motivated to pursue positions of authority in which they have control over others. Competition motivates them. They like meeting new people and tend to be sociable [32]. With a strong drive, extraverts tend to function well in highly stressful environments. Those dominant in agreeableness have high emotional intelligence and value positive relationships with others. They tend to have empathy that influences high sensitivity to others, putting their own needs behind those of others. With a high emotional intelligence, individuals high in agreeableness are able to work well with others. They manage their own emotions and are able to not allow negative emotions to get in their way.

Those with high conscientiousness are characterized by dependability, motivation to achieve, and commitment to success [33]. They tend to be ethical and have high integrity in their work. Highly conscientious employees tend to have a high need for achievement with an internal locus of control. They want to be successful in accomplishing their goals but still take calculated risks. Neuroticism is opposite of emotional stability and indicates a stressand anxiety-prone personality. Neuroticism points to insecurity and low self-confidence. Those with openness to experience as their dominant personality trait tend to be highly flexible, independent-minded, with an ability to think critically in exploring new directions and ideas [33]. They tend to become absorbed in finding new avenues [31,34]. Interestingly, strong openness to experience in individuals tends to reflect a more cognitive disposition than affective or behavioral [30].

While extraversion, agreeableness, openness to experience, and conscientiousness can be perceived as personal resources depending on the context or situation in which they may surface, neuroticism surely creates a challenge for employees in the workplace and hence can be viewed as a job demand. Neuroticism as the tendency to feel and show emotional instability, stress, worry, and anxiety, may be related to workaholism as it is more likely to create a compulsive need or addiction to work [1,9]. Workaholic employees are dedicated to their work, and researchers have asserted that the drive behind this dedication is the employee's need to validate his or her feelings of self-worth [22]. In describing workaholism, employees are driven to work from pressures beyond what is normally expected, resulting in a significant investment in time and energy [35]. As job demands exceed job resources when neuroticism is the dominant dispositional trait, HWI is likely to shift toward the workaholism end of the continuum.

Personality influences subjective well-being, such as happiness and life satisfaction [36]. Aggressive behavior, for example, is negatively associated with agreeableness [37] and conscientiousness [38]. Dominant traits of conscientiousness, extraversion, agreeableness, and openness to experience, are likely to be viewed as resources on the job that lead to subjective well-being experiences. The work engagement end of the HWI continuum results from an abundance of perceived job resources available to the person [28]. With work 
engagement, employees have a positive work experience in their jobs-with increased vigor, dedication, and absorption [13].

Proposition 1. (A) Neuroticism as a dominant Five Factor Model trait is positively related to the workaholism type of HWI as perceived job demands outweigh the job resources. (B) Extraversion, agreeableness, openness to experience, and conscientiousness as dominant Five Factor Model traits are positively related to the work engagement type of HWI as perceived job resources outweigh the job demands.

\subsubsection{Perceived Organizational Context}

The psychological character of the employee work environment influences HWI, workaholism, and work engagement. While workaholism is positively related to an overworked employee climate, work engagement is positively related to an employee growth climate [8]. With increased job resources perceived to be available, employee relationships and motivation are likely to improve in an employee growth climate. An employee's perceived work environment, independent of personality differences (dispositional traits), can differentiate between workaholism and work engagement.

The concept of perceived LMX quality is founded on constructive social exchanges that thrive on mutual trust, reciprocity, and fairness expectations $[39,40]$. When employees perceive their leaders to provide sufficient or plenty of resources enabling them to perform, they tend to reciprocate and become more engaged, exhibiting high motivation, performance, organizational commitment, and OCBs [41].

There is further recent evidence that LMX is a predictor of work engagement [42]. As a personal and job resource, perceived high quality in relationships between a leader and employee will facilitate task achievement and job performance as quality advice and expertise are freely exchanged. High quality LMX also creates a socially and emotionally supportive work environment and hence does not lend itself to compulsive addictive work behaviors such as workaholism $[43,44]$. On the HWI continuum, high quality LMX is more likely to lead to work engagement than workaholism as it contributes to the abundance of job resources.

Proposition 2. LMX is (a) positively related to the work engagement type of HWI as job resources outweigh the job demands; (b) negatively related to the workaholism type of HWI as job demands outweigh the job resources.

Team-member exchange (TMX) refers to the perceived quality of the relationships between an employee and team members $[45,46]$. TMX can be a significant interpersonal resource that influences work outcomes [47]. For example, high TMX associates positively and significantly with outcomes such as organizational citizenship behaviors (OCBs), creativity [48,49], job satisfaction, job performance, and organizational commitment $[45,50]$.

When employees work in a team context, they initiate changes in their environments that tend to create a more favorable context for themselves, both structurally and socially [51]. By increasing available resources and enacting change, employees engage in "job crafting" [52]; one such resource that employees can build in the workplace is high quality TMX where, by helping behaviors, team members create reciprocities that strengthen and facilitate motivation and work engagement [53]. TMX as a perceived construct can foster growth and goal achievement in teams. The higher the perceived quality of team-member exchanges, the higher the probability that team members will engage in constructive work behaviors such as work engagement which helps the team achieve goals and lowers the probability that they will exhibit compulsive behaviors such as workaholism.

Proposition 3. TMX is (a) positively related to the work engagement type of HWI as job resources outweigh the job demands; (b) negatively related to the workaholism type of HWI as job demands outweigh the job resources. 
Employees who perceive that their organization cares about them, values and supports them, and is generally concerned about their well-being are more likely to be committed to and psychologically invested in the organization [54-56]. Eisenberger and colleagues coined the term Perceived Organizational Support (POS) for this construct [57]. Perceptions of support by the organization are typically reciprocated by employees' becoming more involved with their work and having less intent to leave [55,58]. POS leads to a "felt obligation to help the organization, well as the expectation that increased performance on behalf of the organization will be noticed and rewarded" [59] (p. 1856). Subsequent research showed that POS is positively associated with justice and trust perceptions, job satisfaction, job involvement, work engagement, and performance [60,61].

Recent meta-analytic findings have supported the view that POS is positively related to job involvement and employee orientation toward the work [59]. Research has also tied POS to fulfillment of socio-emotional needs, such as those for organization-based selfesteem and affiliation [62]. Further, POS invoking a sense of obligation through a reciprocal social exchange process is related positively to organizational citizenship behaviors.

Based on the JD-R model, POS can be viewed as a significant job resource that leads to positive types of employee work investment. Employees who do not feel supported by the organization (job demands) are less likely to invest in their work, supported by the viewpoint that POS contributes to individual effort and initiative on behalf of the organization as a result of a trade-off between resources and effort [63]. POS, when perceived as low, can be a significant drain on energy and time and can further deplete feelings of self-worth and psychological security [64]. Hence, lower POS can lead to workaholism because employees will be working harder to reach desired goals or to avoid undesirable consequences. Thus, we propose:

Proposition 4. POS is (a) positively related to the work engagement type of HWI as job resources outweigh the job demands; (b) negatively related to the workaholism type of HWI as job demands outweigh the job resources.

\subsubsection{Five Factor Model and Perceived Organizational Context}

Personality impacts perception e.g., [65]. Defining personality with the Big Five traits and perceived organizational context with LMX, TMX, and POS in constructing this conceptual model, a review of research connecting these variables resulted in a few more studies on LMX than on TMX and POS. For example, conscientiousness has been shown to consistently relate significantly and positively to job performance [66]. As LMX quality is dependent on follower competence and achievement, as well as dependability, which are all characteristics associated with conscientiousness $[67,68]$, one can conceptually connect these two variables. Empirically, a meta-analysis showed that conscientiousness is a predictor of LMX [67]. Other predictors of LMX include extraversion [69] and emotional stability [70]. There seems to be limited evidence when it comes to the relationship between LMX and openness to experience or neuroticism [70]. Extraversion and agreeableness were associated significantly with LMX as part of the follower characteristics studied in the Dulebohn and colleagues' meta-analysis [67].

Extraversion has a social component to it, and it is expected that extraverts seek constructive social interactions, which are likely to lead to higher perceived LMX, TMX, and POS. There is evidence that agreeableness predicts adaptive and social helping behaviors and hence is more likely to lead to and contribute to perceptions of a supportive organizational climate with high quality LMX, TMX, and POS [71]. Neuroticism, described by attitudes and emotions such as anger, anxiety, depression, and worry, tends to be limiting for employees in establishing stable social interactions, and the negative outlook in life is more likely to lead to less POS and lower LMX and TMX quality [70,72].

Proposition 5. (A) Neuroticism as a dominant Five Factor Model trait is negatively related to LMX, TMX, and POS. (B) Extraversion, agreeableness, openness to experience, and conscientiousness as dominant Five Factor Model traits are positively related to LMX, TMX, and POS. 


\subsection{Outcomes of HWI}

\subsubsection{Positive Outcomes}

Employee HWI may result in outcomes that are generally considered positive for both the individual employee and the organization. This is not unexpected, as researchers have noted extensively that individuals deem their work to be at least as important as, if not more important than, leisure or community, and an essential source for achievement and maintenance of self-esteem and sense of accomplishment e.g., [73,74]. For example, those working longer hours may be perceived as "heroes" and may be regarded as role models in the workplace [75]. Hence, as individuals invest their time, effort, focus, and commitment in their work, they may derive a sense of job-based self-esteem from it, and further, if individuals identify with the work they are involved in, this will enhance their sense of self-worth and identity [4].

The connections between HWI and positive outcomes were elaborated on in Snir and Harpaz's general model of HWI [76]. Snir and Harpaz proposed that there are different types of heavy work investors. Examples include dispositional types (e.g., workaholics, "addicted to their work"), work-devoted types ("with high passion for their work"), and situational types (e.g., the need-driven and the employer-directed). As a result, they may experience different personal work outcomes contingent on the reason for heavy work investment. Notably, the positive outcomes include work satisfaction and productivity [76] (p. 6).

It was also observed in one study that work-devoted heavy work investors achieved the best results with respect to health-related outcomes [77]. These included stronger positive feelings and health conditions, higher body mass index (BMI), and adequate hours of sleep per night. In contrast, the need-driven investors had the worst well-being and health-related outcomes, including higher stress levels, bodily pain, weariness throughout the day, and aches that interfered with regular activities.

One positive outcome of heavy work investment is performance defined as a collection of behaviors that lead to the achievement of organizational goals [78]. In one cross-national study, it was found that the HWI-effort dimension positively impacted work-related performance in two samples from Romania and Japan [79]. Evidence also exists that connects the work engagement type of HWI positively to performance [80]. As work engagement involves dedication to work, in addition to effort, focus, and time commitment, job performance is likely to increase with high engagement [81,82]. Perceived abundance or availability of job resources is likely to facilitate the association between work engagement and job performance [83].

Positive personal work outcomes are highest in work-devoted investors (high work engagement) and lowest among workaholics [76]. The rationale behind this argument is based on individuals' control over their HWI, such that higher control leads to higher positive results. In a similar vein, evidence exists that job engagement positively predicts work performance, while no significant prediction was ascertained between workaholism and work performance [84].

Proposition 6. Job performance is positively related to the work engagement type of HWI as job resources outweigh the job demands.

Work performance can be a source of job satisfaction [85]. Employees may view their work as a place for self-fulfillment and enjoyment $[86,87]$. As a result of HWI, organizational productivity may improve and individual performance may increase, leading to higher levels of job satisfaction [12]. For example, while some managers may view physical presence and time commitment as a proxy for job performance, effort per se is a more internal and individual phenomenon harder to observe at a glance and hence more intrinsically appraised by the employee [88].

Self-perception theory incorporates the notion that people develop attitudes by observing their own behaviors and draw conclusions from their behaviors to explain the 
behaviors of others [89]. Extending this perspective, one could postulate that, based on the degree of HWI with respect to effort, intensity, and dedication, employees may infer that they are satisfied with their work. HWI may thus be perceived as a behavior employees can gauge relatively autonomously. In one study, evidence was presented on the negative influence of HWI-time commitment (workaholism) and positive influence of HWI-effort (engagement) on job satisfaction [79]. These findings are consistent with extant research on workaholism where time commitment increases when job demands exceed job resources.

In parallel, in another study, it was observed that individuals designated as high in "harmonious passion" (job resource) as in work engagement have higher work satisfaction than those described as "obsessive passionate" (job demand) as in workaholism [90]. Similar results were observed in a variety of investigations in the U.S. and Japan showing that workaholism was negatively related to job satisfaction, while work engagement was positively related $[84,91,92]$.

Proposition 7. Job satisfaction is positively related to the work engagement type of HWI as job resources outweigh the job demands.

The literature connecting heavy work investment and positive affect is based mainly on two theories: (i) The activity theory and (ii) the flow theory. The activity theory "points to the fact that interesting activities can supplement the pleasures that are achieved through people's emotions and physical comforts" [93] (p. 41). The flow theory suggests being involved in an interesting activity is experienced as enjoyable because it balances challenges with skill. The activity is one in which "... people describe their thoughts and actions when they are in that context as spontaneous and effortless, even though what they are doing is often difficult and risky" [94] (p. 387). As heavy work investors invest more hours at work, they might experience more activities with flow than regular workers do. Therefore, they could be expected to exhibit higher levels of positive affect than their regular counterparts.

However, working hours do not always indicate flow of work. The act of working assuages unpleasant feelings (such as anxiety, depression, and guilt) that arise when not working [24,95]. Therefore, the act of working might impact one's mood in general and may help individuals escape or avoid problems in their off-work life [88]. Notably, workaholism may be a means to escape from problems at home [96]. Avoiding these problems by working long hours, workaholics may experience positive affect. The notion of assuaging unpleasant feelings and avoiding unpleasant issues while working overtime was consistently associated with heavy work investors addicted to work (workaholics).

Taking this proposition a step further, it is plausible that a critical component responsible for alleviating negative emotions associated with work is the effort and focus expended to accomplish one's duties-and not just the number of working hours invested in the tasks. The "act of doing" might be expressed more in the effort invested and the focus and dedication exhibited at work, and less in the working hours themselves, which is how work engagement is defined. Therefore, long working hours will assuage negative emotions and express flow only if they also involve high effort, meaning being less like a workaholic and more like an employee with high work engagement. Effortless long hours will not necessarily reduce negative emotions. Moreover, simply logging in long hours does not involve the challenge needed for flow because the "act of doing interesting activities" may be absent.

Proposition 8. Positive affect is positively related to the work engagement type of HWI as job resources outweigh the job demands.

\subsubsection{Negative Outcomes of HWI}

Conversely, what would be the case should job demands outweigh the job resources? In other words, what are the detrimental effects of HWI? Evidence suggests that overtime work has negative effects on health [97]. In fact, there is extant research regarding individual and organizational outcomes of workaholism [12]. For example, workaholics tend to be 
associated with poorer mental and physical health, emotional and cognitive exhaustion, poor sleeping habits, cardiovascular problems, poor social relationships, and work-life conflict e.g., [12,24,98,99].

Areas of disagreement also exist when it comes to affective experiences of workaholics. For example, work enjoyment is an area where researchers disagree, in that, while some argue that true workaholics really enjoy the act of working and experience positive emotions, others state that they have low work enjoyment $[10,88]$. A recent review noted several negative outcomes mainly related to workaholism, such as higher levels of job stress, counterproductive work behaviors and distrust of co-workers, poor family relationships, family dysfunction, greater work-life conflict, as well as lower satisfaction with lives outside of work, burnout, and health issues [99]. In fact, workaholics experience feelings of guilt and anxiety when not working, and hence, while often working longer than others, they tend to suffer from emotional exhaustion, cynicism, and depersonalization.

One negative outcome of employee HWI might be presenteeism, defined as a problem in the workplace because it refers to the "... problem of workers' being on the job but, because of illness or other medical conditions, not fully functioning-can cut individual productivity by one-third or more" [100] (p. 1). Presenteeism might lead to perceptions of ineffectiveness as a result of reduced productivity since it refers to being present at work with the main purpose of just being present on site rather than performing on the job or producing anything [101]. As such, presenteeism might have a negative impact on the organizational performance and productivity. For example, being present at work but using the Internet or mobile phones for personal tasks instead of for work and hence engaging in presenteeism might have detrimental effects for job performance [102]. In parallel, a spillover effect from leaders engaging in presenteesim to employees is also possible [103]. Presenteeism is more likely when perceived job demands exceed job resources. Similarly, spending long periods of time at work (as in workaholism) has been linked to a number of negative outcomes such as increased burnout [4], job stress, work-family conflict [104], and reduced satisfaction and performance [79], all indicative of increased job demands.

Proposition 9. Presenteeism is positively related to the workaholism type of HWI as job demands outweigh job resources.

Stress can be defined as the feeling of emotional strain and pressure in response to demands in the environment, such as events or situations perceived as threatening, demanding, or challenging to the individual [105]. A likely outcome may be fatigue caused by being slowly exposed to heavy work-related stressors [106-110]. Stressors can be interpersonal (e.g., relationship troubles, work-family conflict), task-related (e.g., role ambiguity, role conflict), organization-related (e.g., organizational culture, lack of organizational support), or physical and mental (e.g., daily life, long commute) [106,111].

Burnout, on the other hand, is usually described as a psychological syndrome of emotional exhaustion (feeling drained and used up, with no energy to face another day), experiencing distance from others (cynicism/depersonalization) and feelings of reduced personal accomplishment/efficacy $[112,113]$. Burnout may have detrimental effects on attitudes toward the organization, and employee performance [114], and result in counterproductive work behaviors [42]. Just like stress, burnout is brought on by job demands (e.g., physical demands, risks, and hazards) and/or lack or scarcity of job resources (e.g., knowledge, autonomy, supportive environment) and work stressors [115].

Proposition 10. Stress and burnout are positively related to the workaholism type of HWI as job demands outweigh job resources.

Another possible negative outcome of HWI may be counterproductive work behaviors (CWBs). In recent years, counterproductive work behaviors [42,116] and workplace misbehaviors [116-118] have received considerable attention from researchers, as these manifestations have significant psychological, sociological, and economic implications 
for the working environment $[117,119]$. Counterproductive behaviors might be directed toward the organization or its workers and management, and are costly for both the organization and the individual [120].

These behaviors many times infringe upon important organizational norms and cause damage to an organization's objectives, procedures, productivity, profitability, and employees themselves $[119,121,122]$. Work misbehaviors refer to employees' reducing or withdrawing their input to balance the social exchange process [123], feeling negative toward the organization, feeling less motivated, exhibiting distrust, and even retaliating against the organization [124], which might manifest as harassment, theft, or sabotage [122,125]. Such behaviors are also a result of perceived scarcity of job resources, such as the lack of supervisory support, perceived lack of rewards, and increased job demands, such as the assignment of challenging tasks with little to no training and with no change in financial compensation. When such demands exceed resources, CWBs are more likely to follow.

Proposition 11. CWBs are positively related to the workaholism type of HWI as job demands outweigh job resources.

Work-life balance (WLB) is usually defined as the absence of conflict between work and family or personal roles $[126,127]$. Generally speaking, WLB is the degree to which an individual can simultaneously balance the emotional, behavioral, and time demands of (a) paid work, (b) family, and (c) personal duties and manifests when at least one domain (e.g., work or personal life) interferes with involvement in the other domain (Ref. [128]. This interference may occur because a person's attitudes, emotions, skills, and behaviors in one domain tend to flow into the other, and it can work both ways, for instance, from work to family and vice versa e.g., $[129,130]$.

WLC is more likely when job demands are perceived to exceed the resources present at work. WLC has been linked to a plethora of negative outcomes, such as reduced job satisfaction, lower organizational commitment, lower productivity and performance, lower career satisfaction and success, and higher absenteeism and intention to quit, as well as employee burnout, job stress, poorer physiological and psychological health, substance abuse, and diminished family functioning and more [131]. In addition, workaholics exhibited higher WLC than others [91,126,130,132,133].

Proposition 12. Work-life conflict is positively related to the workaholism type of HWI as job demands outweigh job resources.

\section{Future Research Directions}

Future research should focus on empirically testing this model in a variety of situations across a continuum of HWI. A fruitful area for future research would be to investigate potential moderators of the relationships between HWI types and outcomes. Correlates of workaholism for instance include demographic characteristics such as age, gender, educational level; dispositional variables such as self-esteem or need for autonomy; and work domain factors such as tenure, salary, job demands, and managerial status [9]. Future research should explore how these factors may change the relationships between HWI types and their outcomes.

Evidence suggests that the status of employees (full-time versus part-time) and the national culture in which HWI is scrutinized are important factors that may have an effect on HWI or the relationship between HWI and its outcomes [134]. Some national or organizational cultures may endorse long working hours and an "overwork climates" may inspire employees to invest more time in their work characterized by fewer limitations on routines of excessive time commitment $[135,136]$. A cross-cultural investigation in five countries (Japan, Israel, USA, Belgium, Netherlands) found that although Japanese workers worked more hours than their counterparts in the other countries, there were, nevertheless, similarities among the countries regarding several variables, one of which 
was "work centrality" [136]. Hence, future research should take into account the national and organizational cultural context in which HWI dimensions and types are measured.

Future research needs to focus on establishing the construct validity of workaholism, work engagement, and HWI constructs. Empirically confirming the overlaps, redundancies, and distinctiveness of the measures used in research and establishing their convergent and discriminant validities will advance future research significantly.

\section{Conclusions}

The proposed model integrates three research streams: workaholism, work engagement, and HWI, prompting researchers to view the HWI construct as encompassing both the workaholism and work engagement concepts. Further, the model bases all propositions on the perspective that HWI is an individual decision, and hence it is contingent on individual employee's perceptions of the immediate work environment as well as their personality traits $[15,17]$. This model is open to several future empirical investigations. In particular, the relationships between perceived organizational context variables and HWI dimensions and the relationships between dispositional traits and HWI dimensions need to be empirically verified.

A significant contribution of this model is in conceptualizing HWI on a job demandsresources continuum, such that the opposite of workaholism is no-workaholism and the opposite of work engagement is no-work engagement. Just like Herzberg's two-factor motivation theory, there seems to be a neutral point where an employee may exhibit no to very little workaholism and at the same time no to very little work engagement [137]. These are employees who do the minimum necessary work to be able to stay employed. The two-factor construct of HWI based on perceived job demands and resources outweighing one another is an area of fruitful investigation that can bring conceptual clarity to this stream of research.

Author Contributions: Conceptualization, Visualization, Writing-Original Draft, Supervision, Writing-Review and Editing-F.T.; Writing-Review and Editing-A.T.; Writing-Review and Editing-O.S.; Writing—Review and Editing-E.R. All authors have read and agreed to the published version of the manuscript.

Funding: This research received no external funding.

Data Availability Statement: This paper did not report any data.

Conflicts of Interest: The authors declare no conflict of interest.

\section{References}

1. Clark, M.A.; Michel, J.; Stevens, G.W. Affective reactions and subsequent consequences of heavy work investments. In Heavy Work Investment: Its Nature, Sources, Outcomes, and Future Directions; Harpaz, I., Snir, R., Eds.; Routledge: London, UK; Taylor \& Francis Group: Abingdon, UK, 2015; pp. 187-203.

2. Snir, R. A longitudinal study of heavy time investment in work. Int. J. Organ. Anal. 2018, 26, 153-170. [CrossRef]

3. Van Beek, I.; Taros, T.W.; Schaufeli, W.B.; Brenninkmeijer, V. Heavy work investment: Its motivational make-up and outcomes. J. Manag. Psychol. 2014, 29, 46-62. [CrossRef]

4. Rabenu, E.; Shkoler, O.; Lebron, M.J.; Tabak, F. Heavy-work investment, job engagement, managerial role, person-organization value congruence, and burnout: A moderated-mediation analysis in USA and Israel. Curr. Psychol. 2019, 1-18. [CrossRef]

5. Snir, R.; Harpaz, I. Beyond workaholism: Towards a general model of heavy work investment. Hum. Resour. Manag. Rev. 2012, 22, 232-243. [CrossRef]

6. Astakhova, M.; Hogue, M. A heavy work investment typology: A biopsychosocial framework. J. Manag. Psychol. 2013, 29, 81-99. [CrossRef]

7. Astakhova, M.; Hogue, M. Applying the biopsychological model to examine cross-cultural similarities and differences in heavy work investment behaviors and outcomes. In Heavy Work Investment: Its Nature, Sources, Outcomes, and Future Directions; Harpaz, I., Snir, R., Eds.; Routledge: London, UK; Taylor \& Francis Group: Abingdon, UK, 2015; pp. 322-341.

8. Shaufeli, W.B. Heavy work investment, personality, and organizational climate. J. Manag. Psychol. 2016, 31, 1057-1073. [CrossRef]

9. Clark, M.A.; Michel, J.S.; Zhdanova, L.; Pui, S.Y.; Baltes, B. BAll work and no play? A meta-analytic examination of the correlates and outcomes of workaholism. J. Manag. 2016, 42, 1836-1873. 
10. Shkoler, O.; Rabenu, E.; Vasiliu, C.; Sharoni, G.; Tziner, A. Organizing the confusion surrounding workaholism: New structure, measure, and validation. Front. Psychol. 2017, 8, 1803. [CrossRef]

11. Jacobs, J.A.; Gerson, K. The Time Divide: Work, Family, and Gender Inequality; Harvard University Press: Cambridge, MA, USA, 2004.

12. Di Stefano, G.; Gaudiino, M. Workaholism and work engagement: How are they similar? How are they different? A systematic review and meta-analysis. Eur. J. Work. Organ. Psychol. 2019, 28, 329-347. [CrossRef]

13. Langelaan, A.B.; Bakker, A.B.; van Doornen, L.J.; Schaufeli, W.B. Burnout and work engagement: Do individual differences make a difference? Personal. Individ. Differ. 2006, 40, 521-532. [CrossRef]

14. Schaufeli, W.B.; Bakker, A.B.; Van Rhenen, W. How changes in job demands and resources predict burnout, work engagement, and sickness absenteeism. J. Organ. Behav. 2009, 30, 893-917. [CrossRef]

15. Gillet, N.; Morin, A.; Sandrin, E.; Houle, S. Investigating the combined effects of workaholism and work engagement: A substantive-methodological synergy of variable-centered and person-centered methodologies. J. Vocat. Behav. 2018, 109, 54-77. [CrossRef]

16. Mäkikangas, A.; Schaufeli, W.; Tolvanen, A.; Feldt, T. Engaged managers are not workaholics: Evidence from a longitudinal person-centered analysis. J. Work. Organ. Psychol. 2013, 29, 135-143.

17. Upadyaya, K.; Vartiainen, M.; Salmela-Aro, K. From job demands and resources to work engagement, burnout, life satisfaction, depressive symptoms, and occupational health. Burn. Res. 2016, 3, 101-108. [CrossRef]

18. Schaufeli, W.B.; Bakker, A.B. Job demands, job resources, and their relationships with burnout and engagement: A multi-sample study. J. Organ. Behav. 2004, 25, 293-315. [CrossRef]

19. Schaufeli, W.B. Applying the Job demands-resources model: A 'how-to' guide to measuring and tackling work engagement and burnout. Organ. Dyn. 2017, 46, 120-132. [CrossRef]

20. Demerouti, E.; Bakker, A.; Nachreiner, F.; Schaufeli, W. The job demands-resources model of burnout. J. Appl. Psychol. 2001, 86, 499-512. [CrossRef]

21. Schaufeli, W.B.; Taris, T.W.; van Rhenen, W. Workaholism, burnout, and work engagement: Three of a kind or three different kinds of employee well-being? Appl. Psychol. Int. Rev. 2008, 57, 173-203. [CrossRef]

22. Van Beek, I.; Hu, Q.; Schaufeli, W.; Taris, T.; Schreurs, B. For fun, love, or money: What drives workaholic, engaged, and burned-out employees at work? Appl. Psychol. 2011, 61, 30-55. [CrossRef]

23. Oates, W. Confessions of a Workaholic: The Facts about Work Addiction; World Publishing: New York, NY, USA, 1971.

24. Ng, W.; Sorensen, L.; Feldman, D. Dimensions, antecedents, and consequences of workaholism: A conceptual integration and extension. J. Organ. Behav. 2007, 28, 111-136. [CrossRef]

25. Shimazu, A.; Balducci, C.; Taris, T. Workaholism: About the concept, its antecedents, consequences and prevention. In The Fun and Frustration of Modern Working Life; Taris, T., Peeters, M., De Witte, H., Eds.; Pelckmans: Antwerp, Belgium, 2019 ; pp. 164-176.

26. Rabenu, E. 21st-Century Workplace Challenges: Perspectives and Implications for Relationships in New Era Organizations; Lexington Books: Lanham, MD, USA, 2021.

27. Schaufeli, W.B.; Taris, T.W. A critical review of the job demands-resources model: Implications for improvement work and health. In Bridging Occupational, Organizational, and Public Health: A Transdisciplinary Approach; Bauer, G.F., Hammig, O., Eds.; Springer Science and Business Media: New York, NY, USA, 2014; pp. 43-68.

28. Bakker, A.B.; Albrecht, S. Work engagement: Current trends. Career Dev. Int. 2018, 23, 4-11. [CrossRef]

29. Macdonald, K. Evolution, the Five-Factor model, and levels of personality. J. Pers. 1995, 63, 525-567. [CrossRef]

30. Pytlik-Zillig, L.M.; Hemenover, S.H.; Dienstbier, R.A. What do we assess when we assess a Big 5 Trait? A content analysis of the affective, behavioral, and cognitive processes represented in Big 5 Personality inventories. Personal. Soc. Psychol. Bull. 2002, 28, 847-858. [CrossRef]

31. Goldberg, L.R. The development of markers for the Big-Five factor structure. Psychol. Assess. 1992, 4, 26-42. [CrossRef]

32. McCrae, R.R.; Costa, P.T., Jr. Validation of a five-factor model of personality across instruments and observers. J. Personal. Soc. Psychol. 1987, 52, 81-90. [CrossRef]

33. John, O.P.; Srivastava, S. The Big-Five trait taxonomy: History, measurement, and theoretical perspectives. In Handbook of Personality: Theory and Research; Pervin, L., John, O.P., Eds.; Guilford Press: New York, NY, USA, 1999; pp. 102-138.

34. Tellegen, A.; Atkinson, G. Openness to absorbing and self-altering experiences ("absorption"), a trait related to hypnotic susceptibility. J. Abnorm. Psychol. 1974, 83, 268-277. [CrossRef] [PubMed]

35. Clark, M.A.; Smith, R.W.; Haynes, N.J. The multidimensional workaholism scale: Linking the conceptualization and measurement of workaholism. J. Appl. Psychol. 2020, 105, 1281-1307. [CrossRef]

36. Hayes, N.; Joseph, S. Big 5 correlates of three measures of subjective well-being. Personal. Individ. Differ. 2003, 34, 723-727. [CrossRef]

37. Gleason, K.A.; Jensen-Campbell, L.A.; Richardson, D.S. Agreeableness as a predictor of aggression in adolescence. Aggress. Behav. 2004, 30, 43-61. [CrossRef]

38. Sharpe, J.; Desai, S. The Revised Neo Personality Inventory and the MMPI-2 Psychopathology Five in the prediction of aggression. Pers. Individ. Differ. 2001, 31, 505-518. [CrossRef]

39. Cropanzano, R.; Anthony, E.L.; Daniels, S.R.; Hall, A.V. Social exchange theory: A critical review with theoretical remedies. Acad. Manag. Ann. 2017, 11, 479-516. [CrossRef] 
40. Wang, L.C.; Hollenbeck, J.R. LMX in team-based contexts: TMX, authority differentiation, and skill differentiation as boundary conditions for leader reciprocation. Pers. Psychol. 2018, 72, 271-290. [CrossRef]

41. Hofmann, D.A.; Morgeson, F.P.; Gerras, S.J. Climate as a moderator of the relationship between leader-member exchange and content specific citizenship: Safety climate as an exemplar. J. Appl. Psychol. 2003, 88, 170-178. [CrossRef] [PubMed]

42. Lebrón, M.; Tabak, F.; Shkoler, O.; Rabenu, E. Counterproductive work behaviors toward organization and leader-member exchange: The mediating roles of emotional exhaustion and work engagement. Organ. Manag. J. 2018, 15, 159-173. [CrossRef]

43. Martin, R.; Guillaume, Y.; Thomas, G.; Lee, A.; Epitropaki, O. Leader-Member exchange (LMX) and performance: A meta-analytic review. Pers. Psychol. 2016, 69, 67-121. [CrossRef]

44. Wilson, K.S.; Sin, H.P.; Conlon, D.E. What about the leader in leader-member exchange? The impact of resource exchanges and substitutability on the leader. Acad. Manag. Rev. 2010, 35, 358-372.

45. Banks, G.C.; Batchelor, J.H.; Seers, A.; O’Boyle, E.H., Jr.; Pollack, J.M.; Gower, K. What does team-member exchange bring to the party? A meta-analytic review of team and leader social exchange. J. Organ. Behav. 2013, 35, 273-295. [CrossRef]

46. Seers, A. Team-member exchange quality: A new construct for role-making research. Organ. Behav. Hum. Decis. Process. 1989, 43, 118-135. [CrossRef]

47. Robijn, W.; Euwema, M.C.; Schaufeli, W.B.; Deprez, J. Leaders, teams and work engagement: A basic needs perspective. Career Dev. Int. 2020, 25, 373-388. [CrossRef]

48. Kirrane, M.; Kilroy, S.; Kidney, R.; Flood, P.C.; Bauwens, R. The relationship between attachment style and creativity: The mediating roles of LMX and TMX. Eur. J. Work. Organ. Psychol. 2019, 28, 784-799. [CrossRef]

49. FMalingumu, W.; Stouten, J.; Euwema, M.; Babyegeya, E. Servant leadership, organizational citizenship behavior and creativity: The mediating role of team-member exchange. Psychol. Belg. 2016, 56, 342-356.

50. Shkoler, O.; Rabenu, E.; Tabak, F.; Lebron, M. Leader- and team-member exchanges and their relationships with organizational and interpersonal counterproductive work behaviors: Moderation by envy and group size in a cross-cultural case. J. Work. Organ. Psychol. 2019, 35, 145-156.

51. Bakker, A.B.; Demerouti, E. Multiple levels in job demands-resources theory: Implications for employee well-being and performance. In Handbook of Wellbeing; Diener, E., Oishi, S., Tay, L., Eds.; DEF: Salt Lake City, UT, USA, 2018.

52. Xanthopoulou, D.; Bakker, A.B. Antecedents and consequences of work engagement: A multilevel nomological net. In $A$ Research Agenda for Employee Engagement in a Changing World of Work; Meyer, J.P., Schneider, B., Eds.; Edward Elgar Publishing: Northampton, MA, USA, 2021; pp. 37-51.

53. Schaufeli, W.B.; Bakker, A.B. Defining and measuring work engagement: Bringing clarity to the concept. In Work Engagement: $A$ Handbook of Essential Theory and Research; Bakker, A.B., Leiter, M.P., Eds.; Psychology Press: New York, NY, USA, 2010; pp. 10-24.

54. Baran, B.E.; Shanock, L.R.; Miller, L.R. Advancing organizational support theory into the twenty-first century world of work. J. Bus. Psychol. 2012, 27, 123-147. [CrossRef]

55. Edwards, M.R.; Peccei, R. Perceived organizational support, organizational identification, and employee outcomes testing a simultaneous multifoci model. J. Pers. Psychol. 2010, 9, 17-26.

56. Rhoades, L.; Eisenberger, R. Perceived organizational support: A review of the literature. J. Appl. Psychol. 2002, 87, 698-714. [CrossRef] [PubMed]

57. Eisenberger, R.; Huntington, R.; Hutchinson, S.; Sowa, D. Perceived organizational support. J. Appl. Psychol. 1986, 71 , 500-507. [CrossRef]

58. Eisenberger, R.; Armeli, S.; Rexwinkel, B.; Lynch, P.D.; Rhoades, L. Reciprocation of perceived organizational support. J. Appl. Psychol. 2001, 86, 42-51. [CrossRef] [PubMed]

59. Kurtessis, J.N.; Eisenberger, R.; Ford, M.T.; Buffardi, L.C.; Stewart, K.A.; Adis, C.S. Perceived organizational support: A meta-analytic evaluation of organizational support theory. J. Manag. 2017, 43, 1854-1884. [CrossRef]

60. DeConinck, J.B. The effect of organizational justice, perceived organizational support, and perceived supervisor support on marketing employees' level of trust. J. Bus. Res. 2010, 63, 1349-1355. [CrossRef]

61. Tabak, F.; Hendy, N.T. Work engagement: Trust as a mediator of the impact of organizational job embeddedness and perceived organizational support. Organ. Manag. J. 2016, 13, 21-31. [CrossRef]

62. Lee, J.; Peccei, R. Perceived organizational support and affective commitment: The mediating role of organization-based self-esteem in the context of job insecurity. J. Organ. Behav. 2007, 28, 661-685. [CrossRef]

63. Cropanzano, R.; Mitchell, M.S. Social exchange theory: An interdisciplinary review. J. Manag. 2005, 31, 874-900. [CrossRef]

64. Mudrack, P.E. Understanding workaholism: The case for behavioral tendencies. In Research Companion to Working Time and Work Addiction; Burke, R.J., Ed.; Edward Elgar: Cheltenham, UK, 2006; pp. 108-128.

65. Hiemstra, A.M.F.; Oostrom, J.K.; Derous, E.; Serlie, A.W.; Born, M. Applicant perceptions of initial job candidate screening with asynchronous job interviews. J. Pers. Psychol. 2019, 18, 138-147. [CrossRef]

66. Barrick, M.R.; Mount, M.K. The big five personality dimensions and job performance: A meta-analysis. Pers. Psychol. 1991, 44, 1-26. [CrossRef]

67. Dulebohn, J.H.; Bommer, W.H.; Liden, R.C.; Brouer, R.L.; Ferris, G.R. A meta-analysis of antecedents and consequences of leader-member exchange: Integrating the past with an eye toward the future. J. Manag. 2012, 38, 1715-1759. [CrossRef]

68. Graen, G.B.; Scandura, T.A. Toward a psychology of dyadic organizing. Res. Organ. Behav. 1987, 9, $175-208$. 
69. Phillips, A.; Bedeian, A. Leader-Follower Exchange Quality: The Role of Personal and Interpersonal Attributes. Acad. Manag. J. 1994, 37, 990-1001.

70. Bernerth, J.B.; Armenakis, A.A.; Feild, H.S.; Giles, W.F.; Walker, J.H. The influence of personality differences between subordinates and leaders perceptions of LMX: An empirical investigation. Group Organ. Manag. 2008, 33, 216-240. [CrossRef]

71. Graziano, W.G.; Habashi, M.M.; Sheese, B.E.; Tobin, R.M. Agreeableness, empathy, and helping: A person $\times$ situation perspective. J. Personal. Soc. Psychol. 2007, 93, 583-599. [CrossRef]

72. Bernerth, J.B.; Armenakis, A.A.; Feild, H.S.; Giles, W.F.; Walker, H.J. Is personality associated with perceptions of LMX? An empirical study. Leadersh. Organ. Dev. J. 2007, 28, 613-631. [CrossRef]

73. Harpaz, I.; Meshoulam, I. Difference in the meaning of work in Israel: Workers in high-tech versus traditional work industries. J. High. Technol. Manag. Res. 2004, 15, 163-182. [CrossRef]

74. Snir, R.; Harpaz, I. To work or not to work: Non-financial employment commitment and the social desirability bias. J. Soc. Psychol. 2002, 142, 635-644. [CrossRef] [PubMed]

75. Shimazu, A.; Kubota, K.; Bakker, A.B. How Workaholism Affects Employees and Their Families. In Heavy Work Investment; Harpaz, I., Snir, R., Eds.; Routledge: New York, NY, USA, 2015; pp. 171-186.

76. Snir, R.; Harpaz, I. A General Model of Heavy Work Investment: Introduction. In Heavy Work Investment: Its Nature, Sources, Outcomes, and Future Directions; Harpaz, I., Snir, R., Eds.; Routledge: London, UK; Taylor \& Francis Group: Abingdon, UK, 2015; pp. 3-30.

77. Snir, R.; Harpaz, I. Beyond workaholism: Differences between heavy work investment (HWI) subtypes in wellbeing and health-related outcomes. Int. J. Workplace Health Manag. 2021, in press. [CrossRef]

78. Campbell, J.P. The definition and measurement of performance in the New Age. In The Changing Nature of Performance: Implications for Staffing, Motivation and Development; Ilgen, D.R., Pulakos, E.D., Eds.; Jossey-Bass: San Francisco, CA, USA, 1999 ; pp. $339-429$.

79. Popa, I.; Ştefan, S.C.; Albu, C.F.; Popa, Ş.C.; Vlad, C. The impact of national culture on employees' attitudes toward heavy work investment: Comparative approach of Romania vs. Japan. Amfiteatru Econ. 2020, 22, 1014-1029.

80. Bakker, A.B.; Bal, P.M. Weekly work engagement and performance: A study among starting teachers. J. Occup. Organ. Psychol. 2010, 83, 189-206. [CrossRef]

81. Demerouti, E.; Cropanzano, R. From thought to action: Employee work engagement and job performance. In Work Engagement: A Handbook of Essential Theory and Research; Bakker, A., Leiter, M., Eds.; Psychology Press: New York, NY, USA, 2010 ; pp. 147-163.

82. Yalabik, Z.Y.; van Rossenberg, Y.; Kinnie, N.; Swart, J. Engaged and committed? The relationship between work engagement and commitment in professional service frms. Int. J. Hum. Resour. Manag. 2015, 25, 1602-1621. [CrossRef]

83. Wei, F.; Li, Y.; Zhang, Y.; Liu, S. The interactive effect of authentic leadership and leader competency on followers' job performance: The mediating role of work engagement. J. Bus. Ethics 2018, 153, 763-773. [CrossRef]

84. Shimazu, A.; Schaufeli, W.B.; Kamiyama, K.; Kawakami, N. Workaholism vs. work engagement: The two different predictors of future well-being and performance. Int. J. Behav. Med. 2015, 22, 18-23. [CrossRef]

85. Judge, T.A.; Kammeyer-Mueller, J.D. Implications of core self-evaluations for a changing organizational context. Hum. Resour. Manag. Rev. 2011, 21, 331-341. [CrossRef]

86. Harpaz, I. The current state of heavy work investment and future development. In Heavy Work Investment: Its Nature, Sources, Outcomes, and Future Directions; Harpaz, I., Snir, R., Eds.; Routledge: London, UK; Taylor \& Francis Group: Abingdon, UK, 2015; pp. 361-373.

87. Shamai, O. The relationship between heavy work investment and employees' happiness. In Heavy Work Investment: Its Nature, Sources, Outcomes, and Future Directions; Harpaz, I., Snir, R., Eds.; Routledge: London, UK; Taylor \& Francis Group: Abingdon, UK, 2015; pp. 204-222.

88. Shkoler, O.; Rabenu, E.; Tziner, A. The dimensionality of workaholism and its relations with internal and external factors. Rev. Psicol. Trab. Organ. 2017, 33, 193-203. [CrossRef]

89. Bem, D.J. Self-perception theory. In Advances in Experimental Social Psychology 6; Berkowitz, L., Ed.; Academic Press: New York, NY, USA, 1972; pp. 1-49.

90. Houlfort, N.; Philippe, F.L.; Vallerand, R.J.; Ménard, J. On passion and heavy work investment: Personal and organizational outcomes. J. Manag. Psychol. 2014, 29, 25-45. [CrossRef]

91. Bonebright, C.A.; Clay, D.L.; Ankenmann, R.D. The relationship of workaholism with work-life conflict, life satisfaction, and purpose in life. J. Couns. Psychol. 2000, 47, 469-477. [CrossRef]

92. Burke, R.J.; Fiksenbaum, L. Work motivations, work outcomes, and health: Passion versus addiction. J. Bus. Ethics 2008, 84, 257-263. [CrossRef]

93. Diener, E.; Suh, E.; Oishi, S. Recent findings on subjective wellbeing. Indian J. Clin. Psychol. 1997, $24,25-41$.

94. Csikszentmihalyi, M. The contribution of flow to positive psychology. In Laws of Life Symposia Series. The Science of Optimism and Hope: Research Essays in Honor of Martin E.P. Seligman; Gillham, J.E., Ed.; Templeton Foundation Press: West Conshohocken, PA, USA, 2000; pp. 387-395.

95. Andreassen, C.S.; Griffiths, M.; Hetland, J.; Pallesen, S. Development of a work addiction scale. Scand. J. Psychol. 2012, 53, 265-272. [CrossRef] [PubMed]

96. Baruch, Y. The positive wellbeing aspects of workaholism in cross cultural perspective. Career Dev. Int. 2011, 16, 572-591. [CrossRef] 
97. Dembe, A.E.; Erickson, J.B.; Delbos, R.G.; Banks, S.M. The impact of overtime and long work hours on occupational injuries and illnesses: New evidence from the United States. Occup. Environ. Med. 2005, 62, 588-597. [CrossRef] [PubMed]

98. Andreassen, C.S. Workaholism: An overview and current status of the research. J. Behav. Addict. 2014, 3, 1-11. [CrossRef] [PubMed]

99. Taris, T.W.; Schaufeli, W.; Verhoeven, L.C. Workaholism in the Netherlands: Measurement and implications for job strain and work-nonwork conflict. Appl. Psychol. 2005, 54, 37-60. [CrossRef]

100. Hemp, P. Presenteeism: At work-but out of it. Harv. Bus. Rev. 2004, 82, 49-58.

101. Rabenu, E.; Aharoni-Goldenberg, S. Understanding the relationship between overtime and burnout. Int. Stud. Manag. Organ. 2017, 47, 324-335. [CrossRef]

102. Wajcman, J.; Bittman, M.; Brown, J.E. Intimate connections: The impact of the mobile phone on work/life boundaries. In Mobile Technologies: From Telecommunications to Media; Routledge: London, UK, 2009; pp. 9-25.

103. Dietz, C.; Zacher, H.; Scheel, T.; Otto, K.; Rigotti, T. Leaders as role models: Effects of leader presenteeism on employee presenteeism and sick leave. Work. Stress 2020, 34, 300-322. [CrossRef]

104. Butnaru, R.C.; Anichiti, A.; Haller, G.I.B.A.P. Heavy work investment from the perspective of cultural factors and outcomes by types of investors. Amfiteatru Econ. 2020, 22, 1159-1181.

105. Hardie, E.; Kashima, E.; Pridmore, P. The influence of relational, individual and collective self-aspects on stress, uplifts and health. Self Identity 2005, 4, 1-24. [CrossRef]

106. Chen, M. The impact of expatriates' cross-cultural adjustment on work stress and job involvement in the high-tech industry. Front. Psychol. 2019, 10, 2228. [CrossRef] [PubMed]

107. Lloyd, C.; King, R.; Chenoweth, L. Social work, stress and burnout: A review. J. Ment. Health 2002, 11, 255-265. [CrossRef]

108. Maslach, C.; Jackson, S.; Leiter, M. Maslach Burnout Inventory Manual; Consulting Psychologists Press: Mountain View, CA, USA, 1996.

109. Milbourne, C.C.; Wilkinson, J.S. Chasing infinity: The fear of disconnecting. Am. Commun. J. 2015, 17, 1-14.

110. Zastrow, C. Understanding and preventing burn-out. Br. J. Soc. Work. 1984, 14, 141-155.

111. Yu, K.; Tang, H.; Gong, R.; Dong, J.; Hu, S. Effects of the application of multimedia to library use education on learning motivation and learning satisfaction. EURASIA J. Math. Sci. Technol. Educ. 2018, 14, 2987-2994.

112. Jackson, S.E.; Maslach, C. After-effects of job-related stress: Families as victims. J. Organ. Behav. 1982, 3, 63-77. [CrossRef]

113. Tziner, A.; Buzea, C.; Rabenu, E.; Shkoler, O.; Truta, C. Understanding the relationship between antecedents of heavy work investment (HWI) and burnout. Amfiteatru Econ. 2019, 21, 153-176. [CrossRef]

114. Tourigny, L.; Baba, V.V.; Han, J.; Wang, X. Emotional exhaustion and job performance: The mediating role of organizational commitment. Int. J. Hum. Resour. Manag. 2013, 24, 514-532. [CrossRef]

115. Nahrgang, J.D.; Morgeson, F.P.; Hofmann, D.A. Safety at work: A meta-analytic investigation of the link between job demands, job resources, burnout, engagement, and safety outcomes. J. Appl. Psychol. 2011, 96, 71-94. [CrossRef] [PubMed]

116. Cohen-Charash, Y.; Mueller, J.S. Does perceived unfairness exacerbate or mitigate interpersonal counterproductive work behaviors related to envy? J. Appl. Psychol. 2007, 92, 666-680. [CrossRef]

117. Bodankin, M.; Tziner, A. Constructive deviance, destructive deviance and personality: How do they interrelate? Amfiteatru Econ. 2009, 11, 549-564.

118. Shkoler, O.; Tziner, A.; Vasiliu, C.; Ghinea, C.N. Are positive and negative outcomes of organizational justice conditioned by leader-member exchange? Amfiteatru Econ. 2021, 23, 240-258.

119. Aubé, C.; Rousseau, V.; Mama, C.; Morin, E.M. Counterproductive behaviors and psychological well-being: The moderating effect of task interdependence. J. Bus. Psychol. 2009, 24, 351-361. [CrossRef]

120. Bennett, R.J.; Robinson, S.L. The past, present, and future of workplace deviance research. In Organizational Behavior: The State of the Science; Greenberg, J., Ed.; Lawrence Erlbaum Associates: Mahwah, NJ, USA, 2003; pp. 247-281.

121. Vardi, Y.; Weitz, E. Using the theory of reasoned action to predict organizational misbehavior. Psychol. Rep. 2002, 91, 1027-1040. [CrossRef] [PubMed]

122. Spector, P.E.; Fox, S.; Penney, L.M.; Bruursema, K.; Goh, A.; Kessler, S. The dimensionality of counterproductivity: Are all counterproductive behaviors created equal? J. Vocat. Behav. 2006, 68, 446-460. [CrossRef]

123. Greenberg, J.; Scott, K.S. Why do workers bite the hands that feed them? Employee theft as a social exchange process. In Research in Organizational Behavior: An Annual Series of Analytical Essays and Critical Reviews; Staw, B.M., Cummings, L.L., Eds.; Elsevier Science: Amsterdam, The Netherlands; JAI Press: Stamford, CT, USA, 1996; pp. 111-156.

124. Skarlicki, D.P.; Folger, R. Retaliation in the workplace: The roles of distributive, procedural, and interactional justice. J. Appl. Psychol. 1997, 82, 434-443. [CrossRef]

125. Bennett, R.J.; Robinson, S.L. Development of a measure of workplace deviance. J. Appl. Psychol. 2000, 85, 349-360. [CrossRef] [PubMed]

126. Peters, P.; Blomme, R.J. Forget about 'the ideal worker': A theoretical contribution to the debate on flexible workplace designs, work/life conflict, and opportunities for gender equality. Bus. Horiz. 2019, 62, 603-613. [CrossRef]

127. Quick, J.D.; Henley, A.B.; Quick, J.C. The balancing act: At work and at home. Organ. Dyn. 2004, 33, 426-438. [CrossRef]

128. Hanson, G.C.; Hammer, L.B.; Colton, C.L. Development and validation of a multidimensional scale of perceived work-family positive spillover. J. Occup. Health Psychol. 2006, 11, 249-265. [CrossRef] [PubMed] 
129. Balmforth, K.; Gardner, D. Conflict and facilitation between work and family: Realizing the outcomes for organizations. New Zealand J. Psychol. 2006, 35, 69-76.

130. Bell, A.S.; Rajendran, D.; Theiler, S. Job stress, wellbeing, work-life balance and work-life conflict among Australian academics. E. J. Appl. Psychol. 2012, 8, 25-37. [CrossRef]

131. Frone, M.R.; Russell, M.; Cooper, M.L. Antecedents and outcomes of work-family conflict: Testing a model of the work-family interface. J. Appl. Psychol. 1992, 77, 65-78. [CrossRef]

132. Tytherleigh, M.Y.; Webb, C.; Cooper, C.L.; Ricketts, C. Occupational stress in UK higher education institutions: A comparative study of all staff categories. High. Educ. Res. Dev. 2005, 24, 41-61. [CrossRef]

133. Wang, J.L. Perceived work stress, imbalance between work and family/personal lives, and mental disorders. Soc. Psychiatry Psychiatr. Epidemiol. 2006, 41, 541-548. [CrossRef]

134. Shkoler, O.; Kimura, T. How does work motivation impact employees' investment at work and their job engagement? A moderated-moderation perspective through an international lens. Front. Psychol. 2020, 11, 38. [CrossRef]

135. Mazzetti, G.; Schaufeli, W.B.; Guglielmi, D. Are workaholics born or made? Relations of workaholism with person characteristics and overwork climate. Int. J. Stress Manag. 2014, 21, 227-254. [CrossRef]

136. Snir, R.; Harpaz, I.; Burke, R. The workaholism phenomenon: A cross-national perspective. Career Dev. Int. $2006,11,374-393$. [CrossRef]

137. Herzberg, F. One more time: How do you motivate employees? Harv. Bus. Rev. 1968, 46, 53-62. 